\title{
An Investigation on the Relationship between Service Quality and Customer Satisfaction: In the Case of CCG CO.
}

\author{
Ali Dehghan \\ Department of Engineering Management, Eastern Michigan University \\ Former Master's student of Tarbiat Modares University \\ 2951 International Dr No 2020C, Ypsilanti, MI, USA 48197 \\ Tel: 1-734-277-4914 E-mail: ali.dehghan3@gmail.com
}

Bahman Zenouzi

Universite Montesquieu Bordeaux IV

CCG CO, Customer Centric Group

No 27, Zohre, Park Way, Chamran, Tehran, Iran

Tel: 98-212-266-5086 E-mail: Chief@ccgccc.at

\author{
Amir Albadvi \\ Professor of IS/IT \\ Industrial Engineering Division, Faculty of Engineering \\ Tarbiat Modares University, Tehran, Iran \\ Tel: 98-218-288-3395Ｅ-mail: albadvi@modares.ac.ir
}

Received: August 4, 2011

doi:10.5539/ibr.v5n1p3

\author{
Accepted: October 7, 2011 \\ Published: January 1, 2012 \\ URL: http://dx.doi.org/10.5539/ibr.v5n1p3
}

\begin{abstract}
Nowadays almost all organizations are realizing the significance of customer centered philosophies. One of the key challenges they are facing is how to manage service quality, which holds a great importance to customer satisfaction. The purpose of this investigation has been to gain a better understanding those of the service quality dimensions that affect customer satisfaction from customers' perspective. Some service quality dimensions have been tested in CCG $\mathrm{CO}$ operations and its relationship with customers in order to explore the relationship between service quality and customer satisfaction. A qualitative approach has been considered for the research. The empirical data has been gathered through in dept interviews. Data analysis has been done in accordance with the research questions and literature review. Finally, conclusions have been derived by answering the research questions. Some of the services qualities dimensions have been addressed in this investigation include reliability, responsiveness, tangibles, empathy, and assurance, and logistic/technical support, fulfillment, pricing and courtesy. SERVQUAL as the most often used approach for, measuring service quality has been to compare customers' expectations before a service encounter and their perceptions of the actual service delivered. The results imply that the quality performance of dimensions have a strong impact on customer satisfaction. Also, price, speed of installation and speed of delivery have been found as new dimensions.
\end{abstract}

Keywords: Service quality, SERVQUAL, Customer satisfaction

\section{Introduction}

Customer Centric Group Companies has got partners in supplying whole range of HV Substation products and has organized engineering and expert groups in a way to be able to provide full range of Generation, $T \& D$ and Utilization skills and all related service. This article examines service quality in a company that is experiencing changes in its competitive environment because of restructuring and deregulation in the industry. It also illustrates a 
recently developed service quality model and methodology for the measurement and analysis of service quality, and identifies specific improvements that must be made to the design and delivery of service to meet and exceed customer expectations. The received wisdom within the electrical substation industry was that the business is totally driven by price and availability at a given time. This article analyses the quality of service offered by CCG CO from both the firm and the customer perspectives to see if this is still the case. It also describes the steps that the company needs to implement in the near future.

CCG CO is the leading electrical substation (PASS) contractors in Iran with additional operations. Its primary customers include other contractors companies in Iran. CCG CO customers believe the price of these offered services are too high and usually this company think about its immediate margin not customers benefits ,also the speed of service delivery is not satisfactory, conversely CCG CO thinks that customers expectations are not logical, so in both side, service provider (CCG CO) \& customers got dissatisfied .These are great discrepancies between perceived performance and expectation from customers points of view (perceived performance is less than expectation) that make them dissatisfied.

It is important that the CCG CO provide customers with high quality services to survive in this highly competitive electrical industry business. Regarding this importance, CCG CO first need to understand the attributes that customers use to judge about service quality and monitor and enhance the service performance. There are numerous studies that identified the key service quality dimensions in other businesses, but relatively little literature has investigated service quality attributes in the electrical industry in Iran and the relationship with customer satisfaction (Jun \& Cai 2001).

Managers in the service sector are under increasing pressure to demonstrate that their services are customer-focused, customer-centered and that continuous performance improvement is being delivered. Given the financial and resource constraints under which service organizations must manage it is essential that customer expectations are properly understood and measured and that, from the customers' perspective, any gaps in service quality are identified. This information then assists a manager in identifying cost-effective ways of closing service quality gaps and of prioritizing which gaps to focus on a critical decision given scarce resources.

While there have been efforts to study service quality, there has been no general agreement on the measurement of the concept. The majority of the work to date has attempted to use the SERVQUAL (Parasuraman et al. , 1985; 1988) methodology in an effort to measure service quality (e.g. Brooks et al., 1999; Chaston, 1994; Edvardsson et al., 1997; Lings and Brooks, 1998; Reynoso and Moore, 1995; Young and Varble, 1997; Sahney et al. , 2004). Taking in to account these developments, it is evident that service researchers need to pay more attention to consumer evaluations of technology-based services (Parasuraman and Grewal, 2000). One of the aims of this study involves the service quality dimensions in CCG CO operations and how they affect customer satisfaction. The other aim of this study is to discover how the relative importance of the service quality dimensions can be described for CCG CO in relation with the satisfaction.

\section{Customer Satisfaction}

Customer satisfaction is a critical issue in the success of any business system, traditional or online (Ho \& Wu 1999). In a turbulent commerce environment, in order to sustain the growth and market share, companies need to understand how to satisfy customers, since customer satisfaction is critical for establishing long-term client relationships (Patterson et al. 1997). It is evidenced by the fact that over the last five years, customer satisfaction surveys have become common in many financial institutions. Thus, a fundamental understanding of factors impacting customer satisfaction is of great importance to commerce. Furthermore, the need for research in customer satisfaction has been accentuated by the increasing demand for the long-term profitability of dotcom companies and traditional companies (Pather, Erwin \& Remenyi, 2002). Customer satisfaction can be obtained when the actual performance exceeds the expectations of those being served (Dehghan \& Shahin, 2011). Relationship between Satisfaction and Service Quality Service quality is the key to measure user satisfaction (Pitt et. al., 1995).

\section{Service Quality}

Service quality is a concept that has aroused considerable interest and debate in the research literature because of the difficulties in both defining it and measuring it with no overall consensus emerging on either (Wisniewski, 2001). There are a number of different "definitions" as to what is meant by service quality. One that is commonly used defines service quality as the extent to which a service meets customers' needs or expectations (Lewis and Mitchell, 1990; Dotchin and Oakland, 1994a; Asubonteng et al., 1996; Wisniewski and Donnelly, 1996). Service quality can thus be defined as the difference between customer expectations of service and perceived service. If expectations are greater than performance, then perceived quality is less than satisfactory and hence customer dissatisfaction occurs 
(Parasuraman et al., 1985; Lewis and Mitchell, 1990). Some important definitions of service quality are coming as following:

Parasuraman et al., $(1985,1988)$ : Service quality is determined by the differences between customer's expectations of services provider's performance and their evaluation of the services they received. Asubonteng et al. (1996): Service quality can be defined as 'the difference between customers' expectations for service performance prior to the service encounter and their perceptions of the service received".

Always there exists an important question: why should service quality be measured? Measurement allows for comparison before and after changes, for the location of quality related problems and for the establishment of clear standards for service delivery. Edvardsen et al. (1994) state that, in their experience, the starting point in developing quality in services is analysis and measurement. SERVQUAL as the most often used approach for, measuring service quality has been to compare customers' expectations before a service encounter and their perceptions of the actual service delivered (Gronroos, 1982; Lewis and Booms, 1983; Parasuraman et al., 1985).

Just over a decade ago, Parasuraman et al. (1985) initiated a research stream that many consider to be the most comprehensive investigation into service quality. Briefly, Parasuraman et al. (1985) proposed service quality to be a function of pre-purchase customer expectations, perceived process quality, and perceived output quality. They defined service quality as the gap between customers' expectations of service and their perceptions of the service experience, ultimately deriving the now-standard SERVQUAL multiple-item survey instrument (Parasuraman et al., 1988).

The SERVQUAL instrument has been the predominant method used to measure consumers' perceptions of service quality. It has five generic dimensions or factors and is stated as follows (van Iwaarden et al., 2003):

- Tangibles: Physical facilities, equipment and appearance of personnel.

- Reliability: Ability to perform the promised service dependably and accurately.

- Responsiveness: Willingness to help customers and provide prompt service.

- Assurance: (Including competence, courtesy, credibility and security). Knowledge and courtesy of employees and their ability to inspire trust and confidence.

- Empathy: (Including access, communication, understanding the customer). Caring and individualized attention that the firm provides to its customers.

\section{Discussion}

A study was undertaken in 2005 to develop a clear understanding of the company's service system and the status of its service quality from a customer's viewpoint. We used the service quality model and methodology developed by Parasuraman, Zeithmal and Arash Shahin. The conceptual is describing Relationship between service quality and customer satisfaction derived from the studied done by Zethaml et al. (2000; 2002). Five Service quality dimensions have been selected form the studied done by Van Iwaarden et al. (2003).

(Insert Figure 1 Here)

Interviews based on 5 important aspects of service quality (Tangibles, Reliability, Responsiveness, Assurance and Empathy) were conducted with CCG CO president and a number of its customers. These interviews provided the necessary background information on the service system. The next step involved an analysis and listing of the customer's expectations and measuring the gap between perceived performance and customer's expectations. A listing of the current quality attributes for CCG CO was made immediately after the initial interview with 2 customers and CCG CO's president. All the interviews were conducted based on 5 dimensions of service quality and finally the gap between perceived performance and expectation of side, service provider and customers, were measured in discrepancy diagram.

(Insert Figure 2 Here)

\section{Conclusion}

The findings imply that the Assurance issue is the utmost concern by CCG customers .Based on the literature review and Assurance dimension is categorized by 4 categories: Competent, Courtesy, Security of CCG services and Credibility ,So CCG CO has to hire much more expert staffs to do more projects in order to get better experiences, also those employees should have right attitude to convince the customers and totally make the CCG CO more competent in order to prevail its competitors, otherwise customers will switch to other firms.

The findings reveal because of the name of service provider, Customer Centric Group CO, customers can expect whatever they request or want logically or illogically, so a big gap occurred between the service provider's 
perception and customer's expectation in the case of responsiveness of CCG CO (Service provider), therefore customers must adjust their expectations and service provider should modify its perception. The findings also indicate that quick response is one of the key drivers of customer satisfaction or dissatisfaction, which consists with the prior study. More importantly, the findings also show that some customers expect and need personalized services from the CCG CO. Personalized services could build good relationship with customers, simultaneously gain trust and loyal customers.

In the case of Reliability, the findings reveal that the CCG CO should try to speed up installation time by using much more expert engineers and technicians, also based on causing more trust and satisfaction in customers and create confidential atmosphere, the products have to be delivered faster and customers must pay the costs on time and without delay, because CCG CO is buying all the equipments cash and sell it by related services in payment, otherwise CCG CO will not be able to do its duties and finally both side will be dissatisfied.

The most effective factor among service quality dimensions that has not been found in theory, was Pricing. The findings of this study imply that reasonable price and cost of the services is the most important factors in terms of customer satisfaction, all the customers believe the service costs are too much expensive, So CCG must decrease the costs and prices in order to be survived in this competitive and complex market otherwise it will lose this market thoroughly. Three more dimensions that have not been identified in theory were found in this research that should be mentioned as service quality aspects: Technology Update, Logistical or Technical Equipment and Personalization or Customization, that should be mentioned in increment of CCG CO's service quality and generally for all Service Providers, in order to retain the customers and create more satisfaction. A total of nine service quality dimensions were identified and found by this study:

- Tangibles;

- Responsiveness;

- Reliability;

- Assurance

- Empathy;

- Pricing;

- Technology Update;

- Logistical or Technical Equipment;

- Personalization and customization.

Among them, fist five dimensions are consistent with the variables that mentioned in the frame of reference. We tested them as the core service quality dimensions of CCG CO. From qualitative empirical data, we identified pricing as another important quality criterion in CCG CO services Moreover.

The last dimensions are the new finding in this study. In addition, the first 5 dimensions share the same meaning with the service quality determinants derived within the context of traditional services industries by prior research.

All these nine dimensions are significant criteria and factors to judge services that are provided by CCG CO, simultaneously to identify and measure customers' experiences and preference. However, considering limited resources of CCG CO, Pricing and first five key dimensions should be more significant and focused by the CCG CO. All of the nine dimensions tend to have strong impacts on either customers' satisfaction or dissatisfaction, depending on the quality performance of those dimensions.

\section{References}

Anderson, E. W., \& Sullivan, M. W. (1993). The antecedents and consequences of customer satisfaction for firms. Marketing science Journal, 12(2). http://dx.doi.org/10.1287/mksc.12.2.125

Asubonteng, P., Mccleary, K. J., \& Swan, J. E. (1996). SERVQUAL revisited: a critical review of service quality, The Journal of Services Marketing, 10(6), 62-81. http://dx.doi.org/10.1108/08876049610148602

Awad, E. M. (2000). The Structure of E-Commerce in the Banking Industry: An Empirical Investigation. S1GCPR 2000 Evanston Illinois USA.

Bahia, K., \& Nantel, J. (2000). Areliableand valid measurement scale for the perceived service quality of banks. International Journal of Bank Marketing, 18(2), 84-91. http://dx.doi.org/10.1108/02652320010322994

Bellini, N. (2002). Perceived quality in the delivery of Business support services: a Conceptual Framework (With practical Implication), European seminar on support services for micro small and sole proprietor's businesses. 
Bitner, M. J., Booms, B. H., \& Tetreault, M. S. (1990). The Service Encounter: Diagnosing Favorable and Unfavorable Incidents. Journal of Marketing, 54(1). http://dx.doi.org/10.2307/1252174

Boulding, W., Kalra, A., Staelin, R., \& Zeithaml, V. A. (1993). A Dynamic process model of service Quality: from expectations to behavioral intentions. Journal of Marketing Research, 30(1), 7-27. http://dx.doi.org/10.2307/3172510

Cadotte, E. R., Woodruff, R. B., \& Jenkins, R. L. (1987). Expectations and norms in models of consumer satisfaction. Journal of Marketing Research, 24(3), 305-314. http://dx.doi.org/10.2307/3151641

Caruana, A., \& Malta, M. (2002). Service loyalty-The effects of service quality and the mediating role of customer satisfaction. European Journal of Marketing, 36(7/8), 811-828. http://dx.doi.org/10.1108/03090560210430818

Churchill, G. A., \& Surprenant, C. (1992). Investigation into the Determinant of Customer Satisfaction. Journal of Marketing Research, 19, 491-504. http://dx.doi.org/10.2307/3151722

Churchill, G. A., \& Surprenant, C. (1992). Research Strategy in Studies of Information Systems. MIS Quarterly.1989.33-50. http://dx.doi.org/10.2307/3151722.

Cooper, D. R., \& Schindler, P. S. (2003). Business Research Methods 8th edition. McGraw-Hill Companies.

Creswell, J. W. (2003). Research Design: Qualitative, Quantitative and Mixed Methods Approach. (2nd ed.). Sage Publication, Inc.

Cronin, J. J., \& Taylor, S. A. (1992). Measuring Service Quality: A Reexamination and Extension. Journal of Marketing, 56(7), 55-68. http://dx.doi.org/10.2307/1252296

Daniel, E. (1999). Provision of electronic banking in the UK and Ireland. International Journal of Bank Marketing, 17(5), 211-32. http://dx.doi.org/10.1108/02652329910258934

Dehghan, A., \& Shahin, A. (2011). Customer Loyalty Assessment-A Case Study in MADDIRAN, the Distributor of LG Electronics in Iran. Business Management and Strategy, 2(1).

Parasuraman, A., Berry, L. L., \& Zeithaml, V. A. (1994). Alternative Scales for Measuring Service Quality: A Comparative Assessment Based on Psychometric and Diagnostic Criteria. Journal of Retailing, 70(3), 201-308. http://dx.doi.org/10.1016/0022-4359(94)90032-9

Parasuraman, A., Zeithamal, V. A., \& Berry, L. L. (1988). SERVQUAL: A Multiple-Item Scale for Measuring Consumer Perceptions of Service quality. Journal of Retailing, (1).

Parasuraman, A., Zeithaml, V. A., \& Berry, L. L. (1985). A conceptual model of service quality and its implications for future research. Journal of Marketing, 49(3). http://dx.doi.org/10.2307/1251430

Pitt, L. F., Watson, R. T., \& Kavan, C. B. (1995). Service Quality: A measure of information systems effectiveness. MIS Quarterly, June. http://dx.doi.org/10.2307/249687

Saunders, M., Lewis, P., \& Thornhill, A. (2000). Research Methods for Business Students Second Edition. UK: Financial Times, Prentice Hall.

Spreng, R. A., Mackenzie, S. B., \& Olshavky, R. W. (1996). A reexamination of the determinants of customer satisfaction. Journal of Marketing, 60(3), 15-33. http://dx.doi.org/10.2307/1251839

Shahin, A. (2004). SERVQUAL and Model of Service Quality Gaps: A Framework for Determining and Prioritizing Critical Factors in Delivering Quality Services. International conference on quality management, Docs/0077. 


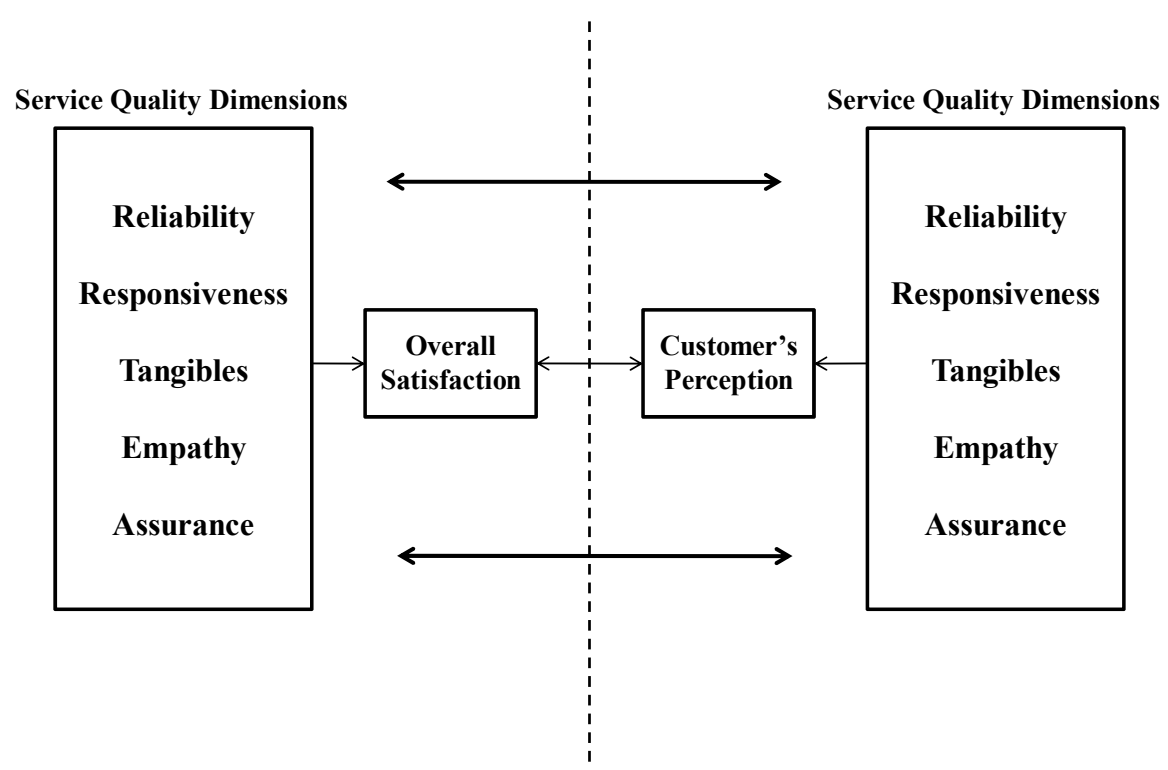

Figure 1. Conceptual Framework

C: Customer's Expectations

S : Service Provider's Perception

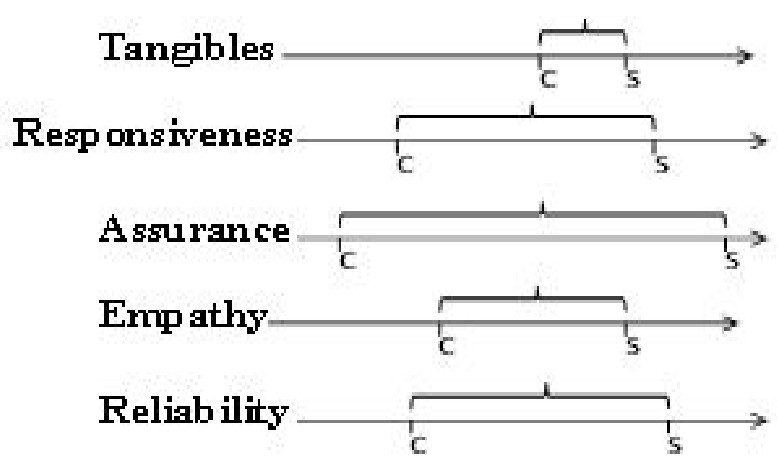

Figure 2. Gap Diagram 